\title{
Kebijakan Kepolisian Sektor Pemayung dalam Penyelesaian Tindak Pidana Penganiayaan Secara Restoratife Justice
}

\author{
Ahmad Zulfikar \\ Fakultas Hukum Universitas Batanghari \\ Jalan Slamet Riyadi-Broni Kota Jambi \\ Correspondence email : ahmadzulfikar_64@Yahoo.com
}

\begin{abstract}
Abstrak. Upaya penanggulangan kejahatan melalui perdamaian berdasarkan Keadilan Restoratife yaitu keadilan bagi semua pihak sangat dirindukan setiap orang. Kepolisian dalam menjalankan tugas penegakan hukum, Penyidik Kepolisian Negara Republik Indonesia mempunyai fungsi, tugas dan wewenang dibidang penyidikan tindak pidana sesuai dengan peraturan perundangundangan yang berlaku. Berdasarkan Peraturan Kapolri Nomor 6 Tahun 2019 tentang Penydikan Tindak Pidana mempunyai peran untuk melakukan usaha pencegahan tanpa harus menggunakan System Peradilan Pidana (SPP) yaitu dengan adanya penyelesaian kasus melalui proses perdamaian. Proses tersebut karena adanya keinginan dari masyarakat yang menginginkan kasusnya segera selesai dan tidak lagi menjadi rumit. Penyelesaian tersebut dapat didukung dengan adanya kewenangan diskresi kepolisian sehingga jenis penelitian adalah yuridis empiris yang bersifat deskriptif, dengan menggunakan data primer dengan cara wawancara dan data sekunder dengan cara studi dokumentasi. Kemudian seluruh data diolah menggunakan analisis data kualitatif. Berdasarkan hasil penelitian maka kebijakan Polsek Pemayung untuk menyelesaikan perkara pidana secara perdamaian (penal police), atau melalui penyelesaian kasus pidana dengan melibatkan pelaku, korban dan/atau keluarganya serta pihak terkait, hal tersebut bertujuan supaya tercapai keadilan bagi seluruh pihak/ keadilan restorative dapat dilakukan, jika tidak menimbulkan keresahan masyarakat atau tidak ada penolakan masyarakat, tidak berdampak konflik social dan perkara masih dalam proses penyelidikan dan penyidikan. Sehingga dapat diarahkan untuk dilakukan penyelesaian dengan melakukan mediasi kepada para pihak baik korban dan pihak tersangka. Dari hasil mediasi tersebut disepakati oleh para pihak, baik dari pihak pelapor maupun pihak terlapor sebagai tersangka mengakui segala perbuatannya. Dan dari hasil mediasi tersebut terjadi kesepakatan bersama para pihak (korban dan tersangka) dan dibuatlah surat perdamaian dan pencabutan Laporan Polisi oleh korban namun sesudah itu, korban datang dan meminta kembali supaya melanjutkan kasusnya, penyidik menjelaskan bahwa kesepakatan itu sudah menjadi perjanjian kedua pihak dan bersifat mengikat serta kasus itu pun sudah dihentikan penyidikannya.
\end{abstract}

Kata Kunci : Keadilan Restoratife, polisi, mediasi

Abstract. Efforts to overcome crime through peace based on Restorative Justice, namely justice for all parties are greatly missed by everyone. In carrying out law enforcement duties, the State Police Investigator of the Republic of Indonesia has the duties, functions, and authorities in the field of investigating criminal acts in accordance with the applicable laws and regulations. Based on the Regulation of the National Police Chief Number .6 of 2019 concerning Criminal Investigation, it has a role to carry out prevention efforts without having to use the Criminal Justice System (SPP), namely by resolving cases through the peace process. This process is due to the desire of the community who wants the case to be completed immediately and no longer be complicated. The resolution can be supported by the police's discretionary authority so that the type of research is descriptive empirical juridical, using primary data by means of interviews and secondary data by means of documentation studies. Then all data were processed using qualitative data analysis. Based on the research results, the Pemayung Police Sector policy is to settle criminal cases peacefully (penal police), or through the settlement of criminal cases involving the perpetrator, victim and/or their family and related parties, with the aim of achieving justice for all parties/restorative justice can be carried out, if it does not cause public unrest or there is no community rejection, it will not have an impact on social conflict and the case is still in the process of investigation and investigation. So that it can be directed to a settlement by conducting mediation to the parties, both the victim and the suspect. From the results of the mediation, it was agreed by the parties, both from the reporting party and the reported party as a suspect, admitting all his actions. And from the results of the mediation there was an agreement with the parties (victim and suspect) and a letter of peace was made and the revocation of the Police Report by the victim but after that, the victim came and asked again for the case to be continued, the investigator explained that the agreement had become an agreement of both parties and was binding and the investigation has been discontinued.

Keywords: Restorative Justice, police, mediation.

\section{PENDAHULUAN.}

Salah satu bentuk kejahatan yang seringkali terjadi di sekitar kita adalah kejahatan berbentuk kekerasan seperti penganiyaan. Tindakan penganiayaan yang semakin marak terjadi dari berbagai sumber merupakan suatu pertanda bahwa hal tersebut merupakan cerminan dari perilaku masyarakat yang kurang terkontrol dengan baik disebabkan oleh tingkat pendidikan yang rendah dan buruknya pengaruh lingkungan pergaulan. ${ }^{1}$ Perselisihan secara personal atau

${ }^{1}$ Andi Hamzah, Asas-Asas Hukum Pidana, Rineka Cipta, Jakarta, 1994, hal. 18. 
kelompok dapat menjadi suatu faktor yang bisa menyebabkan timbulnya kekerasan yang berakhir dengan tindakan penganiayaan. ${ }^{2}$

Pada Kitab Undang-Undang Hukum Pidana, delik penganiayaan adalah wujud tindakan yang bisa merugikan orang lain dalam segi fisik ataupun menghilangkan nyawa orang lain. ${ }^{3}$ Bukan sekedar itu, adanya peraturan pidana terhadap tindak penganiayaan yang bisa mengakibatkan cedera berat maupun mengakibatkan hilangnya nyawa orang lain harus dinilai sebagai suatu tindakan yang sangat menimbulkan kerugian pada korban sebagai subyek hukum yang harus memperoleh keadilan. ${ }^{4}$

Pada dasarnya, perbuatan yang bersinggungan pada tindakan penganiayaan seperti hal tersebut, harus dipahami dan diaplikasikan secara tepat pada penegak hukum untuk mencapai keadilan yang diharapkan. ${ }^{5}$ Dengan demikian melalui pengamatan secara jeli dan cermat pada unsur-unsur tindakan yang sesuai perumusan delik terhadap tindakan yang diperbuat pelaku bisa dijadikan strategi yang tepat untuk memberi keadilan untuk setiap individu yang memiliki kasus tindak pidana penganiayaan. ${ }^{6}$

Berdasarkan pendapat Doctrine memaknai penganiayaan sebagai masing-masing tindakan yang diperbuat secara sengaja yang menyebabkan luka ataupun rasa sakit terhadap orang lain. Adapun yang mengartikan penganiayaan ialah secara sengaja menyebabkan luka ataupun rasa sakit, unsur sengaja tersebut wajib tercantum pada surat tuduhan, berdasarkan ilmu pengetahuan/ doktrin hukum pidana penganiayaan memiliki unsur antara lain :

1. Ada kesengajaan.

2. Ada perbuatan.

3. Ada akibat dari tindakan (yang ditujukan), yakni :

a. Rasa sakit terhadap tubuh.

b. Luka terhadap tubuh.

Unsur pertama berbentuk kesalahan (unsur subyektif), unsur kedua dan ketiga berbentuk unsur obyektif. Tindak pidana penganiayaan merupakan tindak pidana yang diperbuat pada tubuh terhadap seluruh tindakan sehingga menyebabkan rasa sakit ataupun luka di tubuh hingga nyawa yang hilang. Tindak aniaya tercantum pada BAB XX II, Pasal 351s/d Pasal 355 yakni antara lain : 1. Penganiayaan biasa Pasal 351 Kitab Undang-Undang Hukum Pidana (KUHP). 2. Penganiayaan ringan Pasal 352 KUHP. 3. Panganiayaan berencana Pasal 353 KUHP. 4. Penganiayaan berat Pasal 354 KUHP. 5. Penganiayaan berat Pasal 355 KUHP.

Tindak pidana aniaya sebagaimana diuraikan di atas dapat dilihat dari berkas perkara nomor: LP/B10/II/2020/JAMBI/RES BATANGHARI/SEK Pemayung, yang dilakukan oleh pelaku atas nama saudari Salsadilah Binti Abi terhadap saudari atas nama Siska Amelia Binti Samsy, yang mana kronologisnya pada hari kamis bulan Februari 2020 sekitar pukul 16.30 WIB (Waktu Indonesia Barat) bertempat di RT. 09 desa jembatan mas Kec. Pemayung Kab. Batanghari telah terjadi tindak pidana penganiayaan yang mana pada saat pelapor sedang berjalan untuk pulang kerumah di desa ture dan pada saat sampai di jembatan mas RT.09 pelapor diberhentikan dan kemudian terlapor marah dan terlapor langsung menarik jilbab dan pelapor turun dan kemudian terlapor memaksa untuk membuka helm dan pelapor tidak mau, dan kemudian helm pelapor dipaksa untuk dibuka dan kemudian langsung memukul pipi dibagian sebelah kanan pelapor, dan tangan pelapor ditarik dengan kuat, atas kejadian tersebut pelapor melaporkan ke Polsek Pemayung.

Dari laporan tersebut polisi melakukan proses penyelidikan dengan membuat Berita Acara Pemeriksaan (BAP), sesuai dengan ketentuan Pasal 108 Ayat (1) KUHP mengatur hal-hal yaitu: Masing-masing individu yang menyaksikan, melihat, mengalami, ataupun merupakan korban dari tindak pidana memiliki hak dalam membuat aduan ataupun pelaporan pada penyelidik secara tertulis ataupun lisan.

Dari ayat (1) tersebut dikatakan sebagai "hak". Sebagai "hak", adalah sesuatu yang bisa digunakan ataupun tidak dipakai. Tujuan dari penyelidikan ialah menetapkan dapat didakwa peristiwa tertentu untuk dilaksanakan penyidikan ataupun peristiwa tertentu diduga sebagai tindak pidana.

Penyidikan merupakan rangkaian tindak penyidik perihal dan berdasarkan proses yang diaturkan UndangUndang dalam mengumpulkan dan pembuktian di mana melalui pembuktian tersebut dapat menerangkan ataupun mengungkap tindak pidana yang dialami dan didapati pelakunya.

Dalam Pasal 6 KUHAP, Penyidik dikarenakan memiliki wewenang, menerima pengaduan ataupun laporan dari seseorang mengenai tindak pidana; berbuat tindak pertama ketika ditempat kejadian; meminta memberhentikan

\author{
2 Ibid \\ ${ }^{3}$ Chazawi, Adami, Pelajaran Hukum Pidana I, Raja Grafindo Persada, Jakarta, 2005, hal. 13 \\ ${ }^{4}$ Ibid \\ ${ }^{5}$ Andi Hamzah, Op.Cit, hal. 23 \\ ${ }^{6}$ Tongat, Dasar-Dasar Hukum Pidana Dalam Perspektif Pembaharuan, UMM Press, Malang, 2009, hal. 37.
}


tersangka dan melakukan pemeriksaan identitas terhadap tersangka; menangkap, menahan, menggeledah, menyita, dan lain-lain.

Dari tahap penyidikan dan penyelidikan atas laporan tindak pidana yang dicantumkan pada Kitab UndangUndang Hukum Acara Pidana tersebut juga diatur pada Peraturan Kapolri No: 6 Tahun 2019 mengenai Penyidikan Tindak Pidana juncto SE Kapolri No: 6 tahun SE/8/VII/2008 mengenai implementasi restorative justice (keadilan restoratif) pada perkara pidana. Terhadap prinsip restorative justice (keadilan restoratif) tidak dapat diartikan sebagai metode pemberhentian perkara secara damai, namun untuk memenuhi rasa keadilan masing-masing pihaknya yang terkait pada perkara pidana dengan usaha menghubungkan masyarakat, korban, dan pelaku di mana penyidik/penyelidik sebagai mediatornya, sementara penyelesaian perkara yakni berupa perjanjian perdamaian dan mencabut hak penuntutan oleh korban yang harus diminta hakim dari jaksa penuntut umum dalam mengugurkan wewenang penuntutan korban dan penuntutan umum.

Beberapa metode menyelesaikan perkara pidana yang menggambarkan implementasi prinsip restortifve Justice (keadilan restoratif) dan bisa menjadi tolak ukur untuk menerapkan prinsip restortifve Justice (keadilan restoratif) pada perkara pidana sebagai acuannya yaitu :

1. Pasal 76 ayat (1) KUHP, terkecuali perihal keputusan hakim masih kemungkinan dilakukan pengulangan, orang tidak diperbolehkan dituntut 2 kali dikarenakan tindakan hakim Indonesia pada dirinya sudah diadili melalui keputusan yang menjadi tetap;

2. Pasal 7 ayat (1) UU Tahun 2012 No. 11 mengenai system Peradilan Pidana Anak terhadap pemeriksaan, penyidikan, dan penuntutan anak di pengadilan negeri harus dilakukan diversi;

3. Pasal 15 ayat (2) UU Tahun 1999 No. 42 mengenai jaminan Fidusia dan Sertipikat penjaminan Fidusia memiliki daya eksekusi yang serupa terhadap putusan pengadilan yang sudah mempunyai intenitas hukum tetap;

4. Pasal 51 ayat (7) UU Tahun 2001 No. 21 mengenai Otonomi Khusus untuk propinsi Papua bahwasannya dalam melepaskan tersangka pidana oleh tuntutan pidana berdasarkan kebijakan hukum pidana yang diberlakukan, dibutuhkan surat persetujuan supaya dilaksanakan oleh Ketua Pengadilan Negeri yang didapatkan dari Kepala Kejaksaan Negeri terkait pada lokasi timbulnya perkara pidana;

Menurut G.P Hoefnagels, Penanggulangan kejahatan pada dasarnya bisa digolongkan ke dalam 2 jenis, yakni penanggulangan kejahatan dengan cara non penal dan penanggulangan kejahatan secara penal. ${ }^{7}$ Penal policy adalah wujud menanggulangi tindak pidana dengan berfokus terhadap upaya represif sesudah timbulnya tindak pidana, sementara non penal policy cenderung berfokus terhadap upaya preventif sebelum timbulnya tindak pidana.

Dalam segi kasarnya bisa digolongkan bahwa usaha terhadap menanggulangi tindak pidana melalui upaya "penal" menunjukkan kecenderungan mengarah terhadap cara "repressive" (penumpasan, pemberantasan dan penindasan) sesudah tindak pidana terjadi, sementara upaya "non penal" cenderung mengarah terhadap pendekatan "preventife" (pengendalian, pencegahan, dan penangkalan) sebelum tindak pidana terjadi. ${ }^{8}$ Disebut sebagai difrensiasi secara kasar dikarenakan upaya repesif secara umum juga bisa dinilai sebagai upaya preventif pada makna luasnya.

Salah satu upaya Kepolisian Republik Indonesia dengan menerbitkan Peraturan Kapolri Tahun 2019 No: 6 mengenai Penyidikan Tindak Pidana dengan menerapkan keadilan restoratif yaitu penanggulangan kejahatan melalui proses perdamaian. Ketentuan ini diatur dalam pasal 12 dengan syarat materil dan syarat formil. Syarat Materilnya meliputi perkara yang sedang diproses tidak menyebabkan dampak kekhawatiran publik, tidak memberi dampak konflik sosial, tidak terdapat penolakan masyarakat, dan terdapatnya pernyataan oleh masing-masing pihak yang terkait agar tidak melepaskan hak dan tidak keberatan terhadap hak menuntut di muka hukum. Dan tingkat kesalahan tersangka tidak berat dan pelaku bukan resedivis; tindak pidananya masih pada tahap penyidikan dan penyelidikan. Syarat formalnya adanya surat damai oleh masing-masing pihak (terlapor dan pelapor) dan akta dading (surat pernyataan perdamaian) kedua pihak dan diketahui dari atasan penyidik. Kasus yang dipecahkan dengan jalan perdamaian itu dikarenakan ada kehendak masyarakat yang ingin kasus diselesaikan dengan cepat dan tidak sulit, tapi tetap penyelesaian kasus dengan jalan perdamaian itu harus mendahulukan hak-hak korban, contohnya memperoleh penggantian terhadap kerugian yang dialaminya. Hal itu bisa didukung melalui terdapat wewenang diskresi polisi. Maka dengan kesepakatan untuk berdamai yang telah memenuhi syarat meteri dan formil sudah selesai perkara pidana tersebut, tetapi mengapa dalam perkara tersebut pelapor masih menuntut agar perkara tersebut tetap dilanjutkan. Pertanyaannya apakah syarat formilnya belum diselesaikan, sehingga korban sebagai pelapor merasa kerugiannya belum diselesaikan.

Tujuannya untuk mengetahui tesis ini antara lain: 1. Bagaimana aturan terkait keadilan restoratif pada peraturan perundang-undangan? 2. Bagaimana implementasi keadilan restoratif yang dilaksanakan Kepolisian RI di Kepolisan

\section{${ }^{7}$ Ibid}

${ }^{8}$ Barda Nawawi Arief, Upaya Non Penal di dalam Menanggulangi Kejahatan, Bahan Seminar Kriminotogi VI di Semarang, semarang, 1991, hal. 12 
Resort Pemayung untuk menangani perkara pidana Penganiayaan? 3. Bagaimana kendala dan upaya yang diusahakan Kepolisian RI terkhusus Kepolisan Resort untuk menerapkan keadilan restoratif dalam menangani perkara pidana?

\section{METODE}

Tipe penelitian ini merupakan penelitian sosiologis (yuridis empiris). Dalam penelitian sosiologis memiliki tujuan menganalisa masalah yang dilaksanakan melalui perpaduan bahan-bahan hukum (data sekunder) pada data primer yang didapatkan saat penelitian. Metode pendekatan yang dipergunakan untuk menjelaskan masalah pada skripsi ini yang berjudul "Kebijakan Kepolisian Sektor Pemayung Dalam Penyelesaian Tindak Pidana Penganiayaan Secara Restoratife Justice." (LP/B-10/II/2020/Jambi/Res Batanghari/Sek Pemayung) adalah metode Pendekatan Kasus dan pendekatan Undang-Undang. Sumber "data" yang dipakai peneliti untuk menjawab masalah peraturan Polres Pemayung untuk menyelesaikan Tindak Pidana penganiayaan secara restoratife justice. ialah bersumber pada "data primer dan data Sekunder. dan data sekunder dengan meliputi tiga bahan hukum" yaitu : ${ }^{9}$ Bahan Hukum primer dengan meliputi: hasil wawancara, dan penelitian dilapangan. "Bahan Hukum sekunder merupakan bahan hukum yang menjelaskan bahan hukum primer contohnya karya ilmiah, buku-buku, dan literatur yang berhubungan terhadap masalah." berikutnya "bahan Hukum tersier ialah bahan pendukung yang didapatkan berdasarkan kamus, media massa, lietarture, dan buku-buku."

Pada penelitian ini, data yang digunakan dari pengumpulan data dengan 2 metode yakni: Studi lapangan dan Studi kepustakan. Ada pula metode dalam mengumpulkan data dengan cara: Wawancara, Observasi, dan Membuat Daftar Pertanyaan

\section{HASIL DAN PEMBAHASAN.}

Bagaimana pengaturan mengenai restorative justice di dalam peraturan perundang-undangan?

Keadilan restoratif pada perkembangan peradaban manusia (penghukuman) dan perkembangan mazab hukum negara melakukan pengembalian terhadap mandat ius poniendi dan ius ponale pada publik untuk recovery dan penyembuhan pemulihan ${ }^{10}$. Keadilan restoratif adalah konsep pola pikir yang menanggapi berkembangnya sistem peradilan pidana yang berfokus terhadap kepentingan keterlibatan korban, pelaku, dan masyarakat selaku upaya pemulihan sosial pada interelasi sosial masyarakat. Dalam menyelesaikan kasus secara keadilan restoratif tidak sama terhadap tahap peradilan konvensional. Peradilan konvensional adalah suatu peradilan yang menetapkan kesalahan dan mengatur penderitaan/ kerusakan yang terjadi pada seseorang ataupun beberapa orang pada suatu forum diantara negara dan pelaku tindak pidana berdasarkan peraturan yang sistematis. Keadilan restoratif tahap penyelesaian yang mengaitkan masyarakat, korban, dan pelaku. Hal tersebut seperti yang dinyatakan Howard Zehr di tahun 1990 pada buku miliknya yang menyebutkan: ${ }^{11}$ "Restorative Justice sees things differently... crimes is a violation of people and relationships...it creates obligation to make things right. Justice involves perpetrators, victims and the community to find solutions so that reconciliation, repair, and certainty can be realized". Keadilan restoratif juga menjadi kerangka berpikir yang hanya bisa dipakai untuk menanggapi tindak pidana untuk integrited criminal justice system supaya mencapai kepastian hukum dan kemanfaatan sesudah masing-masing pihaknya memperoleh ataupun merasakan keadilan saat melaksanakannya. Terdapat keuntungan dalam mengamati teori yang dinyatakan Gustav Radbruch bahwa terdapat 3 tujuan hukum (yakni keadilan, kebermanfaatan, dan kepastian) pada pelaksanaan 3 tujuan hukum tersebut melalui penggunaan "asas prioritas". Namun keadilan wajib berada di urutan utama dan pertama daripada kebermanfaatan dan kepastian. Sesuai dengan 3 tujuan itu, tentu saja tidak bsia dilakukan secara kolektif sebab seperti yang dipahami, pada realitanya seringkali mengalami benturan pada manfaatan dan kepastian hukum, pada kepastian hukum dan keadilan, dan kebermanfaatan dan keadilan. ${ }^{12}$ Keadilan restoratif adalah wujud solusi dalam menyesaikan masalah di luar pengadilan. Berdasarkan pendapat Barda Nawawi Arief dimaknai sebagai mediasi penal. Mediasi tersebut dinamakan "mediation in penal matters" ataupun "mediation in criminal cases" yang berdasarkan bahasa Belanda dinamakan "Starfbemiddeling"13. Mediasi penal dipergunakan untuk mewujudkan pertemuan pada korban dan pelaku tindak pidana, dengan demikian umumnya hal tersebut dinamakan "offender victim arrangement" ataupun

9 Barda Nawawi Arief, Bunga Rampai Kebijakan Hukum Pidana (Perkembangan Penyusuanan Konsep KUHP Baru), Kencana Prenada Group, Jakarta, 2008, hlm 1.

${ }^{10}$ Zulfa, Eva A., Pergeseran Paradigma Pemidanaan, Lubuk Agung, Bandung, 2011, hal. 74

${ }^{11}$ Howard Zehr dalam Marlina, Pengembangan Konsep Diversi dan Restorative Justice Dalam Sistem Peradilan Pidana Anak di Indonesia (Studi di Kota Medan), Disertasi, Sekolah Pascasarjana USU, Medan, 2006, hal. 50

12 Zulfa, Eva Achjani, Loc.cit

${ }^{13}$ Barda Nawawi Arief, Mediasi Penal Penyelesaian Perkara di luar Pengadilan, Pustaka Magister, Semarang, 2010, hal. 1- 
"victim offender mendiation". ${ }^{14}$ Praktik mediasi penal timbul sebagai solusi untuk menyelesaikan permasalahan sistem peradilan pidana. Wacana keadilan restoratif juga berusaha dalam mengatur kepentingan pelaku dan korban tindak pidana, dan menemukan alternatif secara efektif pada masing-masing pihaknya, dan menangani sejumlah masalah sistem peradilan pidana. Mediasi penal adalah elemn terhadap konsepsi keadilan restoratif yang menjadikan sistem peradilan pidana di kedudukan mediator.

Peran pihak penegakan hukum terutama Kepolisian RI dalam menegakkan hukum pidana secara umum menjadi fungsionalis hukum pidana, ${ }^{15}$ dengan arti fungsional memiliki peran strategis pada penegakan hukum, Barda Nawawi Arief menyebutkan fungsional hukum pidana bisa terwujud, beroperasi, dan berfungsi dengan cara riil. Fungsionalisasi hukum pidana berkaitan terhadap konkeretisasi ataupun operasionalisasi hukum pidana, di mana secara umum tidak berbeda terhadap penegakan hukum. ${ }^{16}$ Fungsionalisasi hukum pidana bisa dimaknai sebagai usaha dalam menjadikan hukum pidana agar bisa terwujud, bekerja, beroperasi, dan berfungsi dengan baik. Hal tersebut berkaitan terhadap konkeretisasi ataupun operasionalisasi hukum pidana, di mana secara umum tidak berbeda terhadap penegakan hukum. Fungsionalisasi mengandung 3 tahap kebijakan yakni tahapan kebijakan formulatif sebagai tahapan dalam merumuskan hukum pidana dari pihak legislatif. Tahapan kebijakan aplikatif sebagai tahapan menerapkan hukum pidana dari penegak hukum. Tahapan kebijakan administratif, yakni menjadi proses dalam melaksanakan hukum dari pihak eksekusi hukum. ${ }^{17}$ Dalam tahap kebijakan aplikatif tersebut pihak kepolisian bisa mengaplikasikan diskresi dengan penguatan dan pendekatan keadilan restoratif dalam menangani perkara pidana. Diskresi berdasarkan pendapat Erlyn Indarti antara lain: ${ }^{18}$

"untuk memperoleh pemahaman terhadap diskresi paling tidak bisa diidentifikasikan berdasarkan 8 unsur yang terdapat pada definisi diskresi yaitu ketepatan, tindakan, keputusan, pilihan, kebijaksanaan, wewenang, otoritas, ataupun kemerdekaan. Melaui perumusan 8 unsur tersebut, dengan demikian diskresi dengan cara komprehensif dapat diformulasikan sebagai otoritas ataupun kemerdekaan suatu lembaga, seseorang ataupun beberapa orang agar dengan penuh pertimbangan dan bijak menentukan pilihan untuk mengambil keputusan dan melakukan suatu tindakan yang dinilai efektif. Tindakan dalam mengambil keputusan tersebut secara umum menjadi tolak ukur terhadap serangkaian tahap yang panjang, meskipun pada realitanya dapat terjadi dengan cepat, terdapat juga kehati-hatian yang bertolak ukur terhadap intelektualitas yang memadai. Tahap itu juga mengaitkan penilaian ataupun pertimbangan berdasarkan perspektif yang adil. Hingga pilihan yang berkaitan terhadap pengambilan tindakan ataupun pembuatan keputusan. Di samping hal tersebut, pemahaman terhadap istilah diskresi lebih dimaknai seolah-olah sebagai pilihan yang ditentukan. Kemudian tindakan yang dilakukan sesungguhnya adalah produk ataupun hasil berdasarkan diskresi, bukanlah diskresinya sendiri. Kesalahan tersebut ialah terdapat dalam realita bahwa pilihan yang ditentukan adalah hasil berdasarkan diskresi yang tidak terlihat, dengan demikian bisa dilakukan observasi dengan cara langsung. Dalam istilah otoritas ataupun kemerdekaan seharusnya fokus terhadap arti diskresi. Diskresi secara umum merupakan suatu hal yang tidak bisa dihindari, yakni pada peneyelenggaraan tugas ataupun pihak penegakan hukum tersebut, meskipun pada kenyataanya terlihat bertentangan terhadap rule of law. Karaktaristik aturan yang benar-benar terbuka dengan cara logika, membentuk bagian diskresi, paling tidak yang implisit, sehingga tidak bisa ditolak".

\section{Bagaimana penerapan restorative justice yang dilakukan Polri di Polsek Pemayung dalam proses penanganan perkara pidana Penganiayaan?}

Aturan pada keadilan retoratif pada Hukum Pidana Pengaturan hukum pidana terhadap KUHAP dan KUHP pada kerangka tanggung jawab criminal liability (pidana) dan sistem pemidanan tersebut lebih mengganggap sanksi penjara sebagai primadona sanksi terhadap terpidana. Sanksi lainnya hanyalah dinilai sebagai hukuman alternatif. Sesuai aturan hukum pidana pada KUHAP dan KUHP, dengan demikian hakim-hakim yang mengadili perkaraperkara pidana yang membuat pidana kurungan sebagai hukuman utama. Konsep keadilan yang diperlukan dan diharapkan masyarakat, terutama korban tindak pidana itu ialah kondisi sebagaimana sebelum timbulnya tindak pidana. dalam menegakkan hukum yang seharusnya pada sistem peradilan pidana pada tindak pidana yang

${ }^{14}$ Yuarsi Susi Eja, Menggagas Tempat Yang Aman Bagi Perempuan, Cet 1, Pusat Studi Kependudukan dan Kebijakan UGM, Yogyakarta, 2002, hal. 87

${ }^{15}$ Barda Nawawi Arief, Kebijakan Kriminal, Makalah disampaikan pada Seminar Krimonologi VI, Semarang, Tanggal 1618 September 1991, hal. 2, bahwa Upaya menanggulangi kejahatan melalui sarana hukum termasuk hukum pidana merupakan bidang kebijakan penegakan hukum dengan tujuan mencapai kesejahteraan masyarakat. Upaya menangulangi kejahatan adalah bagian integral dari upaya perlindungan masyarakat (social wefare). Dengan dmeikian tujuan utama dari politik kriminal yaitu melindungi masyarakat supaya tercapai kesejahteraan masyarakat.

${ }^{16}$ Barda Nawawi Arief, Teori-teori Kebijakan Pidana, Alumni, Bandung, 1994, hal. 157.

17 Barda Nawawi Arief, Beberapa Aspek Kebijakan Penegakan dan Pengembangan Hukum Pidana, PT. Citra Aditya, Bandung, 1998, hal. 30

${ }^{18}$ Erlyn Indarti, Diskresi dan Paradigma: Sebuah Telaah Filsafat Hukum, Pidato Pengukuhan, Disampaikan pada Upacara Penerimaan Jabatan Guru Besar dalam Filsafat Hukum pada FH UNDIP, Semarang 4 November 2010, hal. 39-41 
digolongkan sebagai delik aduan, penyimpangan yang hanya diancam pidana denda dan menggap sanksi pidana sebagai ultimum remedium bisa menerapkan konsep keadilan restoratif. Keadilan restoratif merupakan konsepsi pemidanaan, namun sebagai konsep pemidanaan bukan hanya sekadar terhadap kebijakan hukum pidana (materil dan formal). Keadilan restoratif juga perlu ditinjau berdasarkan sistem kemasyarakatan dan segi kriminologi. Sesuatu dengan fakta yang ada, sistem pidana yang diberlakukan belum secara penuh memastikan integrated justice (keadilan terpadu), yakni keadilan untuk masyarakat, pelaku, dan keadilan konsep berpikir tersebut yang mendukung ke konsep "keadilan restoratif". Kemudian Bagir Manan ${ }^{19}$, pada tulisan yang dibutanya juga menjelaskan mengenai "keadilan restoratif" memuat prinsip-prinsip, yakni: Memposisikan masyarakat, pelaku, dan korban sebagai pemangku kepentingan yang melakukan kerja sama, membentuk keikutsertaan masyarakat, pelaku, dan korban pada penyelesaian tindak pidana ataupun peristiwa, dan langsung berupaya untuk mencari solusi dalam menyelesaikan dinilai adil untuk masing-masing pihak (win-win solutions)". Merangsang penyelesaian tindak pidana ataupun peristiwa melalui langkah-langkah yang relatif personal dan informal, daripada menyelesaikan melalui cara yang imoersonal dan kaku (formal) yang memakai pola setelah dan sebelum tahap peradilan dilakukan. Sebelum tahap peradilan, arti pada saat "perkara" itu masih di tangan kejaksaan ataupun kepolisian. Yakni berdasarkan inisiatif kejaksanaa, kepolisian, kelompok masyarakat, ataupun seseorang, dilaksanakan upaya penyelesaian tindak pidana itu melalui prinsip ataupun cara-cara Restorative justice (keadilan restoratif). Keadilan restoratif bisa dijalankan ketika perkara dibawa ke Pengadilan. Contohnya Hakim, bisa menyarankan penyelesaiannya berdasarkan prinip-prinsip ataupun cara-cara keadian restoratif. Kemungkinan juga di tengah tahap pengadilan bisa dilakukan upaya penyelesaiannya berdasarkan prinsip keadilan restoratif. Jika ditinjau berdasarkan wujud mediasi dengan tujuan mewujudkan "win-win solution" sebagaimana pada perkara perdata. ${ }^{20}$

Penanganan perkara yang dilakukan oleh Unit Reskrim Polsek Pemayung tindak penganiayaan ringan dan tindak penganiayaan pemberatan seperti halnya pada perkara itu beralasan antara lain: Pertama, kasus penganiyaan ringan berdasarkan keadilan restoratif melalui pertimbangan bahwa dari terlapor dan pelapor sudah berdamai dan ditinjau berdasarkan segi sanksi pidana dihukum pada sanksi pidana kurang dari 5 (lima) tahun. Selain hal tersebut, penyidik dalam Unit Reskrim menganggap jika tindak pidana penganiayaan ringan masih berlanjut di tahap penyidikan bisa berdampak pada munculnya kendala pada ketertiban dan keamanan masyarakat. Kedua, kasus tindak penganiayaan dengan pemberatan dilaksanakan upaya keadilan restoratif dari penyidik terhadap Unit Reskrim Polsek Pemayung melalui pertimbangan Harkamtibmas dan kepentingan umum di mana hal itu dipilih dengan tepat dan dibutuhkan dalam mewujudkan solusi paling baik dan berfungsi dalam mendahulukan asas keseimbangan. Pertimbangan lain yaitu adanya rekonsiliasi (kesepakatan damai) pada masing-masing pihak yang terlibat pada kejadian yang dialami. Prosedur keadilan restoratif bisa dilaksanakan melalui solusi, yakni di luar sistem peradilan dengan tidak mengaitkan bagian sistem peradilan dan pihal penegak hukum. Prosedur dalam menyelesaikan kasus tidak berkaitan pada peradilan pidana.

\section{Bagaimana hambatan dan upaya yang dilakukan oleh Polri khususnya Polsek Pemayung dalam penerapan restorative justice pada proses penanganan perkara tindak pidana penganiayaan?}

Aturan Restorative Justice pada UU Tahun 2002 No. 2 mengenai Kepolisian Republik Indonesia. Kepolisian Negara Republik Indonesia di dalam melaksanakan tugasnya mencakup operasional dan kegiatan kepolisian diberikan discretionary power (wewenang diskresi). Discretionary power merupakan wewenang legal dimana pihak polisi memiliki hak dalam wewenang tersebut dan pihak polisi bisa melakukan pengalihan pada suatu kasus, dengan demikian pelakunya tidak harus berurusan pada peradilan pidana dengan cara formal. ${ }^{21}$ Diskresi bukanlah wewenang, namun upaya lain pihak polisi di mana wajib dipertanggungjawabkan dalam segi norma-norma masyarakat dan secara hukum, Diskresi sangat mudah menimbulkan pelanggaran kekuasaan, dengan demikian harus diawasi secara ketat dan jelas pada implementasinya. Diskresi yang terdapat dalam tugas kepolisian disebabkan ketika pihak kepolisian melakukan tindakan, kemudian diberikan terhadap 2 pilihan apakah memproses berdasarkan kewajiban dan tugas sebagai pihak penegak hukum pidana atau mengabaikan kasus tersebut terhadap pembuatan keputusan diskresi pihak polisi. Hal tersebut memiliki makna tidak menjalankan kewajiban sebagai aparat penegak hukum pidana sesuai dengan hal-hal yang bisa dipertanggungjawabkan secara hukum. Alasan-alasan tersebut dapat berbentuk membimbing pelaku untuk ketertiban ataupun dikarenakan hal-hal yang lain. Secara menyeluruh, alasan-alasan ini juga berkaitan ataupun termasuk pada kerangka tugas preventif kepolisian. Perlindungan hukum dari pihak kepolisian untuk menyidiki dan memberi rasa keadilan kerap dikaitkan terhadap tindakan polisi seperti halnya yang tercantum pada UU Tahun 2002 No. 2 mengenai Polri, yaitu "upaya lainnya" yang ditendensi pada arti "diskresi polisi". Penyidik

1916 Bagir Manan, Retorative Justice (Suatu Perkenalan), Refleksi Dinamika Hukum Rangkaian Pemikiran dalam dekade Terakhir, Jakarta: Perum Percetakan Negara RI, 2008, hal 4.

${ }^{20}$ Ibid, hal 8.

${ }^{21}$ Agus Adrianto, Op. cit, hal. 74 
kepolisian diberikan wewenang yang sifatnya pribadi seperti hal yang tercantum dalam Pasal 7 ayat (1) butir j UU No. 1 Tahun 1981 mengenai KITAB Undang-Undang Hukum Acara Pidana dan Pasal 16 ayat (1) butir 1 dan Pasal 18 Tahun 2002 UU No. 2 mengenai Kepolisian Republik Indonesia yang memberi wewenang pada penyidik Kepolisian RI agar "bisa melakukan upaya lainnya" pada ketentuan-ketentuan khusus dan hal tersebut berkaitan terhadap pemaknaan dari diskresi kepolisian.19 Diskresi kepolisian pada UU Tahun 2002 No. 2 Pasal 18 mengenai Polri menyatakan bahwa "(1). Demi kepentingan umum, aparat Polisi RI Pada pelaksanaan wewenang dan tugasnya bisa melakukan tindakan berdasarkan penilain sendiri. (2). Melaksanakan kebijakan seperti halnya yang tercantum pada ayat (1) hanya bisa dilaksanakan pada kondisi yang sangat diperlukan melalui pengamatan Kode Etik Profesi Kepolisian Negara Republik Indonesia dan peraturan perundang-undangan. Berikutnya pada pemaparan Pasal 18 ayat (1) menyatakan: arti dari "melakukan tindakan berdasarkan penilaian sendiri" merupakan upaya yang bisa dilaksanakan Polri untuk melakukan tindakan yang perlu melalui pertimbangan manfaat berdasarkan tindakan tersebut dan memang demi kepentingan umum". Kepolisian RI telah menjadwalkan penerapan keadilan restoratif untuk memberi keadilan pada publik. Penerapan keadilan restoratif bisa diketahui berdasarkan sejumlah aturan-aturan yang sudah diformulasikan pihak Kepolisian RI, yakni Surat Telegram ataupun Peraturan Kabagreskrim Kepolisian RI mengenai implementasi keadilan restoratif dalam menangani kasus pidana, seperti yang tercantum pada TR Kabareskrim Polri No: TR/1124/XI/2006. Peraturan internal Kepolisian RI berkaitan terhadap keadian restoratif dan mengatur pada kerangka pemberhentian kasus untuk kepentingan umum pada Surat Telegram Rahasia Nomor STR/583/VIII/2012 mengenai implementasi keadilan restoratif oleh Badan Reserse Kriminal terhadap para Dir Resnarkoba, Dir Reskrimum, dan Dir Reskrimsu di mana semua Keplisian Daerah melandasi Pasal 18 UU Kepolisian yakni "bertindak berdasarkan penilaiannya sendiri dan didasari oleh pertimbangan risiko dan manfaat berdasarkan tindakannya itu dan memang demi kepentingan umum". Dalam menemukan landasan hukum secara efektif tersebut kemudian dilakukan penafsiran secara berbeda dari msing-masing penyidik. Adapun yang menilai bahwa landasan hukum pemberhentian penyidikan untuk kepentingan bersama ialah tidak ada pembuktian yang cukup dikarenakan saksi-saksi, korban dan pelapor mencabut pelaporan dan semua informasi yang sudah diberi penyidik, adapun yang melandasi terhadap konsep Restorative Justice (keadilan restoratif) dan alternatif dalam menyelesaikan masalah di luar pengadilan (Alternative Dispute Resolution).

\section{SIMPULAN}

1. Kebijakan mengenai keadilan restoratif pada hukum pidana bisa ditinjau berdasarkan sisi pengaturan, yaitu keadilan restoratif pada kebijakan Perundang-Undangan. Selain hal tersebut, aturan tentang landasan Kepolisian RI untuk menggunakan konsep keadilan restoratif belum terdapat peraturan hukum setara pada undang-undang, dengan demikian pihak Pepolisian RI pada pelaksanaannya masih berpedoman terhadap kebijakan internal kepolisian RI dan UU kepolisian RI. Pada Pasal 18 UU Polri menyebutkan "bertindak berdasarkan penilaiannya sendiri didasari oleh pertimbangan resiko dan manfaat berdasarkan tindakannya itu dan memang demi kepentingan bersama". Ada pun landasan Polri yaitu discretionary power (wewenang diskresi). Discretionary power merupakan wewenang legal dimana pihak polisi memiliki hak dalam wewenang tersebut dan pihak polisi bisa melakukan pengalihan pada kasus tertentu, dengan demikian pelakunya tidak harus berurusan pada peradilan pidana secara formal. ${ }^{22}$.

2. Implementasi keadilan restoratif yang dilaksnakan Kepolisian RI untuk menangani kasus pidana pada Kepolisian Sektor Pemayung bisa ditinjau berdasarkan 2 (dua) hal, yaitu: Pertama, penanganan tindak pidana penganiayaan ringan sebagai pelaku tindak pidana. Kedua, penanganan kasus mengenai Harkamtibmas dan kepentingan umum sesuai penilaiannya sendiri. Dapat disimpulkan secara singkat terhadap penanganan perkara Penganiayaan oleh penyidik Polri pada Unitreskrim Polsek Pemayung dengan kriteria yaitu, kategori tindak pidana yang diancam sanksi pidana hingga 1 (satu) tahun harus diprioritaskan untuk diterapkan diversi, tindak pidana yang diancam sanksi pidana di atas 1 (satu) tahun hingga 5 (lima) tahun dapat dipertimbangkan terhadap penerapan diversi, semua kasus penganiayaan ringan harus diupayakan penerapan diversi terkecuali menyebabkan kerugian pada jiwa dan tubuh. Selain hal tersebut, kerugian yang disebabkan tindak pidana, apabila dampaknya bersifat kebendaan dan tidak ada hubungannya dengan nyawa dan tubuh seseorang, sehingga tingkat kepentingan penerapan prinsip diversi semakin dibutuhkan. Terhadap kepentingan umum dan Harkamtibmas atas dasar penilaian oleh Unit Reskrim Polsek Pemayung melalui kriteria yaitu mempertimbangkan proses penegakan hukum sesuai hukum positif dan apabila penyelesaian melalui restorative justice merupakan suatu hal yang mendesak dengan melihat psikologis masyarakat di wilayahnya serta atas pertimbangan memenuhi rasa keadilan masyarakat, sehingga keputusan diserahkan masing-masing, selama masih bisa dipertanggungjawabkan melalui upaya ultimum remedium dan koordinasi dengan penegak hukum. Selain hal tersebut berbagai langkah Unit Reskrim Polsek Pemayung supaya kasus yang ditangani, penyelesaiannya cenderung secara restorative justice yang mengedepankan asas kemanfaatan

${ }^{22}$ Agus Adrianto, Op. cit, hal. 74 
dan keadilan hukum bukan pendekatan kepastian hukum, pelaksanaanya tanpa pamrih dan tanpa imbalan serta hanya untuk keadilan. Dengan demikian, terlebih dahulu harus dilakukan proses perdamaian.

3. Hambatan dan upaya yang dilakukan oleh Polsek Pemayung, terutama Unit Reskrim ketika menerapkan konsep restorative justice pada penanganan perkara pidana bisa diidentifikasikan sebagai berikut, hambatan berdasarkan hambatan internal dan eksternal berupa kompetensi penyidik pada Unit Reserse Kriminal Polsek Pemayung dibidang pengetahuan hukum, sistem peradilan pidana, peraturan perundang-undangan dan ketrampilan tektis dan teknis penyidikan masih belum maksimal. Hal ini terjadi karena belum semua personel fungsi reskrim mengikuti pendidikan kejuruan fungsi teknis reserse dan ketrampilan pendukung, termasuk dalam hal ini kurangnya pemahaman secara komprehensif terhadap prinsip restorative justice. Upaya yang dilakukan antara lain peningkatan kualitas penyidik pada Unit Reserse Kriminal Polsek Pemayung mengakselerasi restorative justice didasarkan pada aspek terdapatnya komitmen Polri untuk menyelesaikan permasalahan masyarakat dan keinginan kuat setiap personel Polri untuk selalu meningkatkan profesionalismenya.

\section{Saran}

1. Mengingat bahwa belum adanya perangkat aturan yang secara tegas mengatur restorative justice terkait peran Polri maka diharapkan Pemerintah Republik Indonesia mengeluarkan produk berupa peraturan perundang-undangan yang secara khusus mengatur tentang restorative justice minimal dalam bentuk Peraturan Pemerintah.

2. Berdasarkan hasil penelitian maka terlihat ada beberapa hal yang perlu diperbaiki atau ditingkatkan terkait penerapan restorative justice di Polsek Pemayung sebagai berikut: Pertama, perlu adanya SOP penerapan restorative justice di Unit Polsek Pemayung terutama menyangkut penanganan perkara tindak pidana ringan untuk melakukan tindakan diskresi demi kepentingan umum dan Harkamtibmas pada penanganan perkara pidana.

3. Secara umum hambatan yang dialami Polri dalam penerapan restorative justice pada penanganan perkara pidana adalah kewenangan Polri selaku penyidik yang diatur di dalam KUHAP. Di samping itu hambatan yang dialami oleh Unit Reserse Kriminal Polsek Pemayung terkait kompetensi penyidik. Untuk itu, upaya yang dilakukan oleh Polsek Pemayung untuk mengatasi hambatan-hambatan pada pelaksanaan restorative justice adalah Pertama, diharapkan untuk meningkatkan kompetensi penyidik pada Unit Reserse Kriminal Polri Pemayung upaya yang dilakukan yakni perlunya peningkatan pemahaman dan pengetahuan melalui pendidikan dan latihan agar efektifnya penerapan restorative justice dan tindakan penyidik dapat dipertanggungjawabkan. Selain itu, harapannya supaya kerjasama Polri yang ointensif dengan pihak akademisi untuk melakukan kajian terhadap penerapan restorative justice pada penanganan perkara pidana baik mekanisme penyelesaiannya perkara tanpa bersentuhan dengan peradilan pidana maupun di luar sistem peradilan pidana dengan tetap melibatkan aparat penegak hukum.

\section{DAFTAR PUSTAKA \\ Buku}

Achjani, Zulfa, Eva, Pergeseran Paradigma Pemidanaan, Bandung, Penerbit Lubuk Agung, 2011

Arief, Barda Nawawi, Mediasi Penal Penyelesaian Perkara di luar Pengadilan, Pustaka Magister, Semarang, 2010.

,Teori-teori Kebijakan Pidana, Alumni, Bandung, 1994

-,Beberapa Aspek Kebijakan Penegakan dan Pengembangan Hukum Pidana, PT. Citra Aditya, Bandung, 1998

Artasasmita, Romli, Kapita Selekta Hukum Pidana dan Kriminologi, Mandar Maju, Bandung, 1995,

Bungin, Burhan, Analisis Data Penelitian Kualitatif, Pemahaman Filosofis dan Metodologis ke Arah Penguasaan Model Aplikasi, Raja Grafindo Persada, Jakarta, 2003.

Eja, Yuarsi Susi, Menggagas Tempat Yang Aman Bagi Perempuan, Cet 1, Pusat Studi Kependudukan dan Kebijakan UGM, Yogyakarta, 2002.

Fajar, dkk, Dualisme Penelitian Hukum Noramtif \& Empiris, Pustaka Pelajar, Yogyakarta, 2010

Hadisuprapto, dkk: Pemahaman dan Penanggulangan, UNDIP, Semarang, 1996

Harahap, M. Yahya, Pembahasan Permasalahan Dan Penerapan KUHAP, Penyidikan Dan Penuntutan, Sinar Grafika, Jakarta, 2002

Ismail, Chairuddin, Polisi, Demokrasi VS Anarkhi, Yayasan Citra, Jakarta, 2000

Ibrahim, Jhonny, Teori dan Metode Penelitian Hukum Normatif, Boymedia Publishing, Malang, 2006.

Karjadi, M. dan R. Soesilo, Kitab Undang-Undang Hukum Acara Pidana dengan Penjelasan Resmi dan Komentar, Politeia, Bogor, 1997

Soedjono Dirdjosisworo, Pengantar Ilmu Hukum, Raja Grapindo Persada, Jakarta, 2014.

Marzuki, Peter Mahmud, Penelitian Hukum, Kencana, Jakarta, 2005.

Manan, Bagir, Retorative Justice (Suatu Perkenalan),dalam Refleksi Dinamika Hukum Rangkaian Pemikiran dalam dekade Terakhir, Perum Percetakan Negara RI, Jakarta, 2008.

Rahardjo, Satjipto, Ilmu Hukum, PT. Citra Aditya Bakti, Bandung,1996.

Rahardi, H.Pudi, Hukum Kepolisian. Profesionalisme dan Reformasi Polri, Laksbang Mediatama, Surabaya, 2007. 
Ahmad Zulfikar, Kebijakan Kepolisian Sektor Pemayung dalam Penyelesaian Tindak Pidana Penganiayaan Secara Restoratife Justice

Reksodiputro, Marjono, Pembaharuan Hukum Pidana, Lembaga Kriminologi UI, Jakarta, 1995

-------,Bunga Rampai Permasalahan Dalam Sistem Peradilan Pidana, Kumpulan Karangan Buku Ketiga, Pusat Pelayanan Keadilan dan Bantuan Hukum, Jakarta, 1997.

Sapardjaja, Komariah Emong, Ajaran Sifat Melawan Hukum Materiel Dalam Hukum Pidana Indonesia, Studi Kasus tentang Penerapan 